\title{
Evaluation of fungicides and herbicides against groundnut collar rot pathogen Aspergillus niger under in vitro conditions
}

\author{
V. DIVYA RANI*, HARI KISHAN ${ }^{1}$, P. NARAYAN REDDY, G. UMA DEVI AND K. VIJAY KRISHNA \\ KUMAR $^{2}$
}

Professor Jayashankar Telangana State Agricultural University, HYDERABAD (TELANGANA) INDIA

${ }^{1}$ International Crops Research Institute for the Semi-Arid Tropics, Patancheru, HYDERABAD (TELANGANA) INDIA

${ }^{2}$ Acharya N.G. Ranga Agricultural University, GUNTUR (A.P.) INDIA

\section{ARITCLE INFO \\ Received : 17.02 .2017 \\ Revised : 18.03 .2017 \\ Accepted : 22.03.2017}

KEY WORDS :

Groundnut, Collar rot, Aspergillus

niger, Fungicides, Herbicides
*Corresponding author:

divyavallapu@gmail.com

\begin{abstract}
Collar rot of groundnut is caused by Aspergillus niger Van Tieghem. It is a soilborne pathogen, usually the occurrence of collar rot disease during the early stages of crop growth and results in high seedling mortality. The collar rot pathogen produces both seed rot (pre-emergence) and seedling blight symptoms (post-emergence). In case of seed rot, black masses of mycelium were seen on the surface of seed. Later, the pathogen causes rotting of seed. Rotten seed do not emerge from the soil. Collar rot affected seedlings show a circular brownish spot on cotyledon region. Later, the discoloured area rapidly disintegrates spreading to the stem and hypocotyl. The affected plants show general wilting, rotting just below the ground level. An experiment was conducted under in vitro conditions to evaluate the fungicides against the collar rot pathogen apart from these fungicides, some herbicides also evaluated to test their non-target effect against collar rot pathogen. A total of six fungicides and eight herbicides were evaluated by using poisoned food technique. Maximum inhibition $(100 \%)$ of radial growth of A. niger was obtained with tebuconazole at recommended and half recommended dosage and least inhibition was obtained with mancozeb and azoxystrobin. Among herbicides pendimethalin was shown maximum inhibition (100\%) against $A$. niger and least inhibition was observed with herbicide imazythapyr and imazythapyr + imazamox.
\end{abstract}

How to view point the article : Rani, V. Divya, Kishan, Hari, Reddy, P. Narayan, Devi, G. Uma and Kumar, K. Vijay Krishna (2017). Evaluation of fungicides and herbicides against groundnut collar rot pathogen Aspergillus niger under in vitro conditions Internat. J. Plant Protec., 10(1) : 128-133, DOI : 10.15740/HAS/IJPP/10.1/128-133. 